\title{
PERBEDAAN HASIL BELAJAR SISWA PADA MODEL PEMBELAJARAN KOOPERATIF TIPE CIRC DAN MODEL PEMBELAJARAN KONVENSIONAL
}

\author{
Yandry Niak, Wilmintjie Mataheru, dan Darma Andreas Ngilawayan \\ Universitas Pattimura, Ambon Maluku
}

Email: yandryniak63@gmail.com

\begin{abstract}
This study aims to see differences in student learning outcomes in the material system of two-variable linear equations using the CIRC type cooperative model and conventional learning models. This research is comparative research. The experimental class uses the CIRC type cooperative model using teaching materials and student worksheets and control classes using conventional models without teaching materials and student worksheets. The end of the meeting is a test of learning outcomes. The data obtained were then analyzed through: descriptive analysis, t-test statistics, and hypothesis testing. The results showed that there were differences in learning outcomes of Class $\mathrm{X}$ students of SMK Negeri 2 Ambon who were taught using cooperative integrated reading and composition cooperative learning model (CIRC) and conventional learning models on the material of two-variable linear equation systems.
\end{abstract}

Keywords: comparative research, cooperative model, cooperative integrated reading and composition, two-variable linear equation system

\section{PENDAHULUAN}

Matematika merupakan ilmu yang memegang peranan penting dalam perkembangan Ilmu Pengetahuan dan Teknologi. Hal ini disebabkan karena konsepkonsep matematika banyak diterapkan dalam berbagai disiplin ilmu (Tanujaya, et al, 2017). Matematika sebagai ilmu dasar memegang peranan penting dalam perkembangan ilmu dan teknologi dan hal ini sudah diyakini oleh berbagai pihak bahwa matematika mempunyai kontribusi yang cukup besar terhadap perkembangan dan kemajuan bangsa. Menyadari pentingnya peranan matematika dalam berbagai aspek kehidupan maka hasil pendidikan matematika harus dapat membekali anak didik dengan keterampilan dan kemampuan untuk menjawab permasalahan baik sekarang maupun yang akan datang (Pattimukay, 2010). Lebih lanjut Depdiknas (2007) memaparkan beberapa tujuan mempelajari matematika antara lain agar siswa memiliki kemampuan memahami konsep matematika secara luwes, akurat, efisien, dan tepat dalam memecahkan masalah, serta 
memiliki sikap menghargai kegunaan matematika dalam kehidupan, yaitu memiliki rasa ingin tahu, perhatian dan minat dalam mempelajari matematika, sikap ulet dan percaya diri dalam menyelesaikan pemecahan masalah.

Peranan matematika yang sangat substansial, sayangnya tidak diikuti dengan hasil belajar matematika yang memuaskan. Azizah (2010) mengatakan bahwa hasil pelajaran matematika sekolah dasar dan menengah di Indonesia menunjukkan ketidakmampuan siswa menghubungkan antar materi yang dipelajari dan bagaimana pengetahuan itu dimanfaatkan untuk memecahkan persoalan sehari-hari. Padahal memecahkan persoalan sehari-hari dalam ilmu matematika digambarkan pada soal cerita matematika. Sehingga kemampuan siswa dalam menyelesaikan soal cerita matematika, akan menunjukkan kemampuan siswa dalam memecahkan masalah.

Hasil belajar matematika yang kurang memuaskan, dapat disebabkan karena penguasaan konsep yang kurang baik, sehingga jika konsep tersebut disajikan dalam soalsoal aplikasi atau soal cerita maka siswa akan semakin kesulitan. Selain itu kurangnya keterlibatan siswa dalam pembelajaran yang disebabkan karena model konvensional yang membuat siswa menjadi pasif. Ratumanan dalam Molle dan La Moma (2008) mengatakan bahwa, pembelajaran matematika saat ini kurang memberi perhatian pada aktivitas siswa. Guru terlalu mendominasi kegiatan belajar mengajar, sehingga guru ditempatkan sebagai sumber pengetahuan dan berfungsi sebagai pentransfer pengetahuan. Sebaliknya siswa lebih banyak pasif, diposisikan sebagai objek belajar, dikondisikan hanya untuk menunggu transformasi pengetahuan dari guru. Akibatnya, hasil belajar cenderung mengalami penurunan.

Menurut Sanjaya (2011), salah satu masalah yang dihadapi dunia pendidikan kita saat ini adalah proses pembelajaran yang dilakukan secara formal di sekolah masih terlihat lemah. Proses pembelajaran tersusun atas sejumlah komponen atau unsur yang saling berkaitan satu dengan lainnya. Interaksi antara guru dan siswa pada saat proses pembelajaran, memegang peran penting dalam mencapai tujuan yang diinginkan. Adapun kemungkinan kegagalan guru dalam menyampaikan materi disebabkan saat proses pembelajaran, guru kurang membangkitkan perhatian dan aktivitas siswa dalam mengikuti pembelajaran khususnya pembelajaran matematika sehingga akibatnya berdampak pada hasil belajar siswa.

Salah satu tujuan dari pembelajaran matematika pada SMK adalah menerapkan 
matematika sebagai dasar penguasaan kompetensi produktif dan pengembangan diri (UU Nomor 23 Tahun 2006). Sehingga pemahaman dan penguasaan materi pada mata pelajaran matematika sangatlah penting sebagai dasar terhadap penguasaan kompetensi produktif. Namun berdasarkan observasi awal yang dilakukan peneliti saat melakukan Praktek Pengalaman Lapangan (PPL) pada bulan Oktober 2015 di SMK Negeri 2 Ambon, ditemukan bahwa dalam proses pembelajaran di kelas, siswa lebih pasif dan guru yang lebih aktif. Siswa hanya mencatat yang ditulis oleh guru di papan tulis, dan saat guru meminta siswa untuk bertanya, siswa lebih memilih untuk diam. Kemudian peneliti melakukan wawancara dengan seorang guru matematika SMK Negeri 2 Ambon, beliau mengatakan bahwa hasil belajar siswa kelas X pada materi persamaan linier dua variabel masih tergolong rendah. Beliau juga menambahkan bahwa materi sistem persamaan linier dua variabel dari tahun ke tahun siswa sulit dalam memahami cara menyelesaikan materi tersebut, yang disebabkan pada saat pemberian materi, hanya sebagian siswa yang mempunyai perhatian lebih dalam mengikuti proses pembelajaran di kelas.

Proses pembelajaran yang masih menggunakan model konvensional selama ini lebih didominasi oleh guru, sehingga pembelajaran cenderung monoton yang menyebabkan siswa merasa jenuh. Hal ini mengakibatkan siswa menjadi malas belajar dan menjadi pasif serta dapat mengurangi hasil belajar siswa terhadap pembelajaran matematika. Menurut Arends (Trianto, 2009), dalam proses pembelajaran guru selalu menuntut siswa untuk belajar, tapi jarang mengajarkan bagaimana caranya siswa untuk belajar, guru juga menuntut siswa untuk menyelesaikan masalah, tapi jarang mengajarkan bagaimana siswa seharusnya menyelesaikan masalah. Akibatnya, kesulitan yang didapat bukan dari siswa saja, tetapi berasal dari guru juga, karena metode yang digunakan guru adalah metode ceramah, sehingga siswa merasa bosan dalam mengikuti proses pembelajaran. Oleh karena itu, dalam proses belajar matematika, guru perlu mengadakan pembaharuan terhadap strategi, metode dan pendekatan yang tepat sehingga tujuan pembelajaran dapat tercapai.

Model pembelajaran kooperatif merupakan model pembelajaran yang menarik dan dapat memicu siswa untuk ikut secara aktif, serta dapat lebih mengapresiasikan diri dalam berdiskusi. Menurut Trianto (2009), pembelajaran kooperatif disusun dalam sebuah usaha untuk meningkatkan kepemimpinan kepada siswa untuk berinteraksi dan belajar bersama-sama dengan siswa yang berbeda latar belakangnya. Dalam 
pembelajaran kooperatif siswa belajar dalam kelompok-kelompok kecil.

Terdapat berbagai tipe pada model pembelajaran kooperatif diantaranya tipe Cooperative Integrated Reading and Composition (CIRC). Peneliti memilih model pembelajaran CIRC karena CIRC merupakan salah satu tipe model pembelajaran kooperatif yang menyajikan soal-soal dalam bentuk soal cerita. Model CIRC juga melatih siswa belajar secara berkelompok dan guru memberikan materi untuk dipahami siswa, kemudian siswa menyusun kembali pemahaman materi yang sudah didiskusikan dengan kelompoknya. Huda (2013) mengatakan, dalam pembelajaran CIRC, setiap siswa bertanggung jawab terhadap tugas kelompok. Setiap anggota kelompok saling mengeluarkan ide-ide untuk memahami suatu konsep dan menyelesaikan tugas, sehingga terbentuk pemahaman. Kegiatan pokok dalam CIRC untuk memecahkan soal cerita meliputi kegiatan bersama yang spesifik, yaitu: pertama salah satu anggota kelompok membaca atau beberapa anggota membaca secara bergantian, kemudian siswa membuat penafsiran isi soal cerita dengan menulis apa yang diketahui, apa yang ditanyakan dan memisalkan apa yang ditanyakan dengan suatu variabel tertentu, selanjutnya siswa saling membuat ikhtisar atau rencana penyelesaian soal cerita, lebih lanjut siswa menulis urutan komposisi penyelesaian soal, terakhir siswa saling merevisi dan mengedit (jika ada yang perlu direvisi).

Tujuan dari penelitian ini adalah untuk mengetahui tidaknya perbedaan hasil belajar siswa kelas X SMK Negeri 2 Ambon yang diajarkan menggunakan model pembelajaran kooperatif tipe Cooperative Integrated Reading and Composition (CIRC) dengan model pembelajaran konvensional pada materi sistem persamaan linier dua variabel. Penelitian ini diharapkan dapat memberi manfaat untuk semua pihak terutama bagi guru sebagai bahan masukan atau informasi dalam menyusun dan menggunakan model pembelajaran kooperatif tipe Cooperative Integrated Reading and Composition (CIRC) untuk menyajikan materi supaya dapat meningkatkan kualitas proses belajar mengajar dan hasil belajar.

\section{METODE PENELITIAN}

Penelitian ini merupakan penelitian eksperimen dengan menggunakan desain penelitian posttest-only control group design. Penelitian eksperimen menurut Tanujaya (2013) merupakan jenis penelitian dimana peneliti memanipulasi dan mengendalikan 
sistem guna memperoleh data yang bersumber dari proses yang diinginkan. Pengendalian sistem dilakukan melalui pemberian perlakuan pada variable bebas, sehingga pengaruh perlakuan tersebut dapat diukur pada variabel terikat, sedangkan.Setyosari (2012: 187) mengatakan, penelitian posttest-only control group design bertujuan untuk meneliti perbedaan dari suatu perlakuan tertentu terhadap gejala suatu kelompok dengan kelompok lain yang sama tetapi diberikan perlakuan yang berbeda.

Populasi dalam penelitian ini adalah siswa kelas X SMK Negeri 2 Ambon yang terdiri dari 7 kelas dengan jumlah siswa 192.

Tabel 1. Distribusi Nilai Siswa Berdasarkan Nilai Rata-rata Kelas

\begin{tabular}{cccc}
\hline No & Kelas & Rata-rata & Jumlah Siswa \\
\hline 1 & $\mathrm{XA}^{1}$ & 59,31 & 29 \\
2 & $\mathrm{XA}^{2}$ & 59,37 & 29 \\
3 & $\mathrm{XB}^{1}$ & 62,16 & 31 \\
4 & $\mathrm{XB}^{2}$ & 70,25 & 33 \\
5 & $\mathrm{XC}^{1}$ & 58,14 & 15 \\
6 & $\mathrm{XC}^{2}$ & 58,38 & 17 \\
7 & $\mathrm{XD}$ & 50,47 & 38 \\
\hline \multicolumn{5}{r}{ Total } & 192 \\
\hline
\end{tabular}

Teknik pengambilan sampel dalam penelitian ini dilakukan dengan teknik purposive sampling. Menurut Sugiyono (2015: 68) purposive sampling adalah teknik penentuan sampel dengan pertimbangan tertentu. Sampel yang diambil dalam penelitian ini adalah siswa kelas X SMK Negeri 2 Ambon yang dipilih dua kelas sebagai sampel, dengan memperhatikan pada tingkat kemampuan rata-rata siswa dari dua kelas yang relatif sama untuk digunakan dalam penelitian ini, yaitu kelas $\mathrm{XA}^{1}$ sebagai kelas eksperimen dan kelas $\mathrm{XA}^{2}$ sebagai kelas kontrol, sehingga jumlah sampelnya adalah 58 siswa. Kemampuan rata-rata siswa diambil dari nilai tes ulangan harian materi sebelumnya yang diperoleh dari guru.

Perangkat pembelajaran yang digunakan dalam penelitian terdiri dari Rencana Pelaksanaan Pembelajaran (RPP), Bahan Ajar (BA) dan Lembar Kerja Siswa (LKS) yang disusun sesuai model pembelajaran kooperatif tipe CIRC dan model pembelajaran konvensional. Rencana Pelaksanaan Pembelajaran dalam penelitian ini terdiri atas 8 RPP, yaitu 4 RPP untuk kelas eksperimen dan 4 RPP untuk kelas kontrol dengan masingmasing RPP terdiri atas satu kali pertemuan. Dalam proses belajar mengajar di kelas eksperimen, siswa dibantu dengan BA yang dilengkapi dengan LKS, sedangkan pada 
kelas kontrol tidak digunakan BA maupun LKS. Dalam proses pembelajaran di kelas kontrol guru hanya menggunakan RPP.

Teknik analisis data berdasarkan tujuan dan hipotesis penelitian dilakukan dengan menggunakan analisis deskriptif dan analisis inferensia menggunakan Uji-t. Analisis deskriptif, digunakan untuk mendeskripsikan hasil belajar siswa. Hasil belajar yang dimaksud berupa nilai yang diperoleh dengan menggunakan rumus sebagaimana dikemukakan oleh Purwanto (2009).

$$
\text { Nilai }=\frac{\text { jumlah skor yang diperoleh }}{\text { total skor }} \times 100
$$

Selanjutnya, nilai yang diperoleh diklasifikasikan sesuai penilaian acuan patokan (PAP) seperti yang dikemukakan oleh Ratumanan (2006) sebagaimana disajikan pada Tabel 2.

Tabel 2. Distribusi Nilai dan Kualifikasi dalam Penilaian Acuan Patokan

\begin{tabular}{ll}
\hline Kualifikasi & Nilai \\
\hline Baik Sekali & $x \geq 90$ \\
Baik & $75 \leq x<90$ \\
Cukup & $60 \leq x<75$ \\
Kurang & $40 \leq x<60$ \\
Sangat Kurang & $x<40$ \\
\hline
\end{tabular}

Uji-t dilakukan dengan menggunakan SPSS versi 20.0. Sebelum diadakan pengujian hipotesis dengan menggunakan uji-t, terlebih dahulu dilakukan uji prasyarat analisis terhadap data nilai tes akhir siswa yaitu Uji Normalitas dan Uji Homogenitas. Uji Normalitas, dilakukan dengan tujuan untuk mengetahui apakah data pada kedua kelompok sampel yang diteliti berasal dari populasi yang berdistribusi normal atau tidak. Dalam penelitian ini, pengujian normalitas menggunakan uji Chi kuadrat $\left(\chi^{2}\right)$ sebagaimana dikemukakan oleh Sugiyono (2014), yaitu:

$$
\chi^{2}=\sum_{i=1}^{k} \frac{\left(f_{0}-f_{h}\right)^{2}}{f_{h}}
$$

Pengujian dilakukan dengan taraf signifikansi 5\% dan Df $=(k-1)$.

Uji Homogenitas digunakan untuk mengetahui apakah kedua kelas sampel memiliki varians yang homogen atau tidak dalam penelitian ini, pengujian homogenitas varians menggunakan uji $\mathrm{F}$ dengan rumus sebagaimana dikemukanan oleh Sugiyono (2014). 


$$
\mathrm{F}_{\text {hitung }}=\frac{\text { varians terbesar }}{\text { varians terkecil }}
$$

Analisis data kemudian dilanjutkan dengan melakkan uji Hipotesis untuk mengetahui ada tidaknya perbedaan hasil belajar kedua kelas setelah diberi perlakuan model pembelajaran kooperatif tipe CIRC dan model pembelajaran konvensional digunakan uji-t yaitu menggunakan SPSS 20.0.

kriteria pengujiannya adalah sebagai berikut:

$H_{0}$ diterima jika $t_{\text {hitung }}<\mathrm{t}_{\text {tabel }}$ atau Sig. $(2$-tailed $)$ pada output SPSS $>\alpha$

$H_{1}$ diterima jika $t_{\text {hitung }} \geq t_{\text {tabel }}$ atau Sig. $(2$-tailed $)$ pada output SPSS $<\alpha$

Selanjutnya hipotesis yang dimaksud sebagai berikut.

$H_{0}: \mu_{1}=\mu_{2}$, tidak ada perbedaan hasil belajar siswa kelas X SMK Negeri 2 Ambon yang diajarkan dengan model pembelajaran kooperatif tipe CIRC dan model pembelajaran konvensional pada materi sistem persamaan linier dua variabel.

$H_{1}: \mu_{1} \neq \mu_{2}$, ada perbedaan hasil belajar siswa kelas X SMK Negeri 2 Ambon yang diajarkan dengan model pembelajaran kooperatif tipe CIRC dan model pembelajaran konvensional pada materi sistem persamaan linier dua variabel.

\section{HASIL DAN PEMBAHASAN}

Setelah proses pembelajaran pada kelas eksperimen dan kelas kontrol selesai dilakukan, selanjutnya diadakan tes akhir. Data tes akhir siswa yang diperoleh dari kedua kelas dapat digambarkan pada tabel berikut sesuai dengan penilaian acuan patokan (PAP).

\section{Tabel 3. Distribusi Nilai Siswa Berdasarkan Tes Akhir}

\begin{tabular}{llcc}
\hline \multirow{2}{*}{ Kualifikasi } & \multirow{2}{*}{ Nilai } & \multicolumn{2}{c}{ Jumlah Siswa } \\
\cline { 3 - 4 } & & Kelas Eksperimen & Kelas Kontrol \\
\hline Baik Sekali & $x \geq 90$ & 3 & 0 \\
Baik & $75 \leq x<90$ & 14 & 3 \\
Cukup & $60 \leq x<75$ & 8 & 17 \\
Kurang & $40 \leq x<60$ & 4 & 7 \\
Sangat Kurang & $x<40$ & 0 & 2 \\
\hline
\end{tabular}

Berdasarkan Tabel 3 terlihat bahwa terdapat 3 siswa pada kelas eksperimen yang memiliki kualifikasi baik sekali, sedangkan pada kelas kontrol tidak ada siswa yang memiliki kualifikasi sangat baik. Untuk kualifikasi baik terdapat 14 siswa pada kelas eksperimen dan 3 siswa pada kelas kontrol, sedangkan pada kualifikasi cukup sebanyak 
8 siswa dari kelas eksperimen dan 17 siswa dari kelas kontrol. Siswa yang memperoleh nilai dengan kualifikasi kurang pada kelas eksperimen sebanyak 4 siswa dan kelas kontrol sebanyak 7 siswa, dan pada kualifikasi sangat kurang tidak ada siswa pada kelas eksperimen dibandingkan dengan kelas kontrol terdapat 2 siswa. Nilai rata-rata tes akhir pada kedua kelas dapat digambarkan pada tabel berikut.

\section{Tabel 4. Nilai Rata-Rata Siswa Berdasarkan Tes Akhir}

\begin{tabular}{lc}
\hline \multicolumn{1}{c}{ Kelas } & Rata-rata \\
\hline Eksperimen & 74,95 \\
Kontrol & 62,27 \\
\hline
\end{tabular}

Berdasarkan Tabel 4, terlihat bahwa rata-rata hasil belajar siswa dari kelas eksperimen yaitu 74,95 lebih dari kelas kontrol yaitu 62,27.

Selanjutnya uji prasyarat analisa yang terdiri dari uji normalitas dan uji homogenitas, dan pengujian hipotesis yang dilakukan dengan menggunakan uji perbedaan rata-rata atau Uji-t. Uji Normalitas dilakukan dengan menggunakan Uji ChiSquare untuk kedua kelas dan diperoleh hasil sebagaimana disajikan pada Tabel 5.

Tabel 5. Hasil Uji Normalitas $(\alpha=0,05)$

\begin{tabular}{lccc}
\hline \multicolumn{1}{c}{ Kelas } & Sig. & $\boldsymbol{\alpha}$ & Kesimpulan \\
\hline Eksperimen & 1,000 & 0,05 & Terima $H_{0}$ \\
Kontrol & 1,000 & 0,05 & Terima $H_{0}$ \\
\hline
\end{tabular}

Berdasarkan Tabel 5, terlihat bahwa pada kelas eksperimen, nilai Sig. yang dihasilkan lebih besar dari nilai $\alpha=0,05$ yaitu 1,000 . Hal yang sama juga nampak pada kelas kontrol, nilai Sig. lebih besar dari nilai $\alpha=0,05$ yaitu 1,000. Hal ini mengandung pengertian bahwa $H_{l}$ ditolak. Dengan demikian dapat disimpulkan bahwa data penelitian yang diambil adalah berdistribusi normal

Lebih lanjut dilakukan uji Homogenitas menggunakan uji kesamaan dua varians menggunakan uji-F untuk membandingkan varians kedua kelas. Hasil pengujiannya ditunjukkan pada tabel berikut.

Tabel 6. Hasil Uji Homogenitas $(\alpha=0,05)$

\begin{tabular}{cccc}
\hline Kelas & Sig. & $\boldsymbol{\alpha}$ & Kesimpulan \\
\hline $\begin{array}{c}\text { Eksperimen dan } \\
\text { Kontrol }\end{array}$ & 0,865 & 0,05 & Terima $H_{0}$ \\
\hline
\end{tabular}

Berdasarkan Tabel 6, terlihat bahwa nilai Sig. lebih besar dari nilai $\alpha=0,05$ yakni 
0,865. Hal ini berarti $H_{1}$ ditolak, sehingga dapat dikatakan varians kedua kelas adalah homogen.

Setelah diketahui melalui uji prasyarat bahwa sampel yang diambil dinyatakan normal dan homogen, maka selanjutnya dilakukan uji hipotesis dengan menggunakan uji perbedaan rata-rata atau uji t. Hasil pengujian tersebut disajikan pada Tabel 7.

\section{Tabel 7. Hasil Pengujian Hipotesis dengan Menggunakan Uji-t}

\begin{tabular}{|c|c|c|c|}
\hline Kelas & Sig. (2-tailed) & $\alpha$ & Kesimpulan \\
\hline $\begin{array}{l}\text { Eksperimen dan } \\
\text { Kontrol }\end{array}$ & 0,001 & 0,05 & Terima $H_{l}$ \\
\hline
\end{tabular}

Berdasarkan Tabel 7, terlihat bahwa nilai Sig. (2-tailed) lebih kecil dari nilai $\alpha=$ 0,05 yakni 0,001 . Hal ini menunjukkan bahwa pada taraf signifikansi $\alpha=5 \%$, maka $\mathrm{H}_{0}$ ditolak. Dengan demikian dapat dinyatakan bahwa terdapat perbedaan antara hasil belajar siswa kelas X SMK Negeri 2 Ambon yang diajarkan dengan menggunakan model pembelajaran kooperatif tipe CIRC dan hasil belajar siswa yang diajar dengan menggunakan model pembelajaran konvensional pada materi sistem persamaan linier dua variabel.

Pada kelas eksperimen pembelajaran dilakukan sebanyak 4 kali pertemuan dan ditambah 1 kali pertemuan untuk pemberian tes akhir (post test). Dalam proses pembelajaran, siswa dibantu dengan menggunakan perangkat berupa Bahan Ajar (BA) dan Lembar Kerja Siswa (LKS). Kelompok yang dibentuk yaitu sebanyak 6 kelompok, 5 kelompok beranggotakan 5 orang dan 1 kelompok beranggotakan 4 orang. Selanjutnya guru mengelompokkan siswa dalam kelompok untuk berdiskusi dan bekerja sama dalam menyelesaikan serta memecahkan masalah pada BA dan LKS yang diberikan guru.

Pada pertemuan pertama, siswa diberikan BA dan LKS untuk didiskusikan dan dipelajari bersama oleh siswa pada masing-masing kelompok. Ketika guru berkeliling mengawasi kelompok yang sedang belajar, hanya beberapa siswa saja yang bertanya kepada guru, kemudian guru menerangkan pada siswa yang bertanya serta anggota kelompoknya. Pada pertemuan pertama guru kurang memotivasi dan mengingatkan siswa tentang pentingnya memahami bahan ajar. Dalam proses pembelajaran pada pertemuan kedua, ketika guru berkeliling untuk mengawasi siswa, terdapat beberapa siswa yang bertanya kepada guru. Siswa yang bertanya cenderung siswa yang berkemampuan tinggi dan beberapa siswa yang berkemampuan sedang. Sementara siswa lainnya cenderung 
bertanya kepada teman-teman yang sedang mempelajari BA yang dianggap telah memahami materi. Namun, ada juga beberapa siswa yang terlihat hanya melihat teman mereka mempelajari BA tanpa ada usaha untuk mengetahui bagaimana cara menyelesaikannya, padahal menurut Slameto (2003), kerjasama dalam kelompok sangat diperlukan untuk dapat meningkatkan cara berpikir siswa, agar siswa dapat berinteraksi dalam kelompok untuk memecahkan masalah dengan baik.

Setelah waktu mengerjakan LKS selesai, guru mempersilahkan siswa maju mewakili kelompoknya untuk mempresentasikan hasil kerja mereka di depan kelas dan mempersilahkan kelompok lain untuk menanggapi hasil kerja kelompok yang sedang mempresentasikan hasil kerja kelompoknya. Setelah setiap kelompok selesai mempresentasikan hasil kerja kelompoknya, guru mengajak siswa untuk memberikan pujian berupa tepuk tangan kepada kelompok 1 sampai dengan kelompok 6. Pada pertemuan pertama, saat siswa mempresentasikan hasil kerja kelompoknya, guru tidak menyebut nama anggota kelompok secara acak, sehingga yang mempresentasikan hasil kerja kelompok cenderung siswa yang berkemampuan tinggi. Hal ini menyebabkan siswa yang berkemampuan sedang dan rendah seolah-olah terabaikan. Pada pertemuan berikutnya, guru sudah mengingatkan siswa untuk harus memahami hasil kerjanya sehingga mampu mempertanggung jawabkan hasil kerja kelompoknya. Setelah proses pembelajaran telah selesai, guru memberikan tes untuk mengetahui kemampuan siswa terhadap materi yang telah dipelajari. Pada akhir pembelajaran, guru membimbing siswa untuk mengulangi cara menyelsaikan soal cerita dengan menggunakan langkah-langkah dari model CIRC. Pada pertemuan ketiga dan keempat tidak ada masalah dalam mempelajari BA dan menyelesaikan LKS, siswa sudah terlihat saling membantu sesama anggota kelompok dalam mempelajari BA dan LKS, sehingga proses pembelajaran dapat berjalan dengan baik.

Pada kelas kontrol yang diajarkan dengan model pembelajaran konvensional, pelaksanaan penelitian dilakukan sebanyak 4 kali pertemuan dan ditambah 1 kali pertemuan untuk pemberian tes akhir (post test). Pelaksanaan pembelajaran pada kelas yang diajarkan dengan model pembelajaran konvensional, guru menyampaikan materi pembelajaran seperti biasa. Saat proses pembelajaran berlangsung guru banyak mendominasi pembelajaran melalui penyampaian materi pembelajaran sedangkan siswa banyak mencatat dan sebagai pendengar saja. Guru membangun pengetahuan siswa 
dengan menjelaskan materi secara bertahap, memberikan contoh kemudian menjelaskannya, dan memberikan kesempatan pada siswa untuk bertanya pada setiap materi yang dijelaskan. Terlihat beberapa siswa mengajukan pertanyaan dan kemudian dijawab oleh guru, dan ada beberapa siswa yang tidak memperhatikan apa yang disampaikan guru. Hal ini dikarenakan guru terlalu mendominasi proses pembelajaran dengan menyampaikan semua informasi sehingga siswa yang awalnya memperhatikan penjelasan guru lama-kelamaan menjadi bosan dan mencari kesibukan sendiri.

Hal ini sejalan dengan pendapat Ratumanan (2002) mengatakan bahwa, pada model pembelajaran konvensional, guru mendominasi kegiatan belajar mengajar. Guru ditetapkan sebagai sumber utama pengetahuan dan berfungsi sebagai pentransfer pengetahuan, sebaliknya siswa lebih banyak pasif. Siswa mulai serius belajar dan aktif ketika guru mempersilahkan siswa untuk menyelesaikan soal cerita yang berkaitan dengan SPLDV, dan juga ketika siswa diberikan soal-soal latihan. Dalam menyelesaikan soal, guru juga masih membimbing siswa dalam menyelesaikan soal-soal yang diberikan. Setelah siswa selesai mengerjakan soal, guru meminta salah seorang siswa untuk menuliskan penyelesaiannya di depan kelas. Setelah itu guru memberikan umpan balik terhadap hasil pekerjaan siswa, dan menutup pembelajaran bersama siswa kemudian memberikan rangkuman serta tugas untuk diselesaikan siswa.

Berdasarkan pengamatan peneliti, terlihat bahwa siswa pada kelas yang diajarkan dengan model pembelajaran kooperatif tipe CIRC saling bekerja sama dan saling membantu antara satu siswa dengan siswa lainnya selama proses pembelajaran, dibandingkan dengan siswa pada kelas yang diajarkan dengan model pembelajaran konvensional, siswa hanya belajar secara individu dan pembelajaran lebih didominasi oleh guru. Setelah diberikan perlakuan pada kelas eksperimen dan diberikan tes akhir, diperoleh rata-rata hasil belajar siswa sebesar 74,95 dan pada kelas kontrol yang tidak diberikan perlakuan, setelah diberikan tes akhir diperoleh rata-rata hasil belajar siswa sebesar 62,27. Hal ini juga dibuktikan dengan uji perbedaan rata-rata atau uji $t$ menggunakan SPSS 20.0, yaitu nilai Sig. (2-tailed) lebih kecil dari nilai $\alpha=0,05$ yakni 0,001 sehingga mengakibatkan $\mathrm{H}_{1}$ diterima, yang artinya ada perbedaan hasil belajar siswa antara kelas yang yang diajarkan dengan menggunakan model pembelajaran kooperatif tipe CIRC dan model pembelajaran konvensional. 


\section{SIMPULAN}

Berdasarkan hasil penelitian dan pembahasan yang telah diuraikan diatas, maka kesimpulan dari penelitian ini adalah bahwa terdapat perbedaan hasil belajar siswa Kelas X SMK Negeri 2 Ambon yang diajarkan menggunakan model pembelajaran kooperatif tipe cooperative integrated reading and composition (CIRC) dan model pembelajaran konvensional pada materi sistem persamaan linier dua variabel. Adanya perbedaan ini didukung pula dengan hasil pengolahan data untuk uji-t, yakni nilai Sig. (2-tailed) lebih kecil dari nilai $\alpha=0,05$ yakni 0,001 .

\section{DAFTAR RUJUKAN}

Azizah, (2010). Pengaruh Model Pembelajaran Kooperatif Tipe CIRC terhadap kemampuan menyelsaikan soal cerita matematika. (studi eksperimen di SMP Negeri 238 Jakarta. Universitas Islam Negeri Syarif Hidayatulah: Jakarta.

Depdiknas. (2007). Kreatifitas Guru Dalam Pembelajaran. Direktorat Profesi Pendidik: Jakarta.

Huda, M. (2013). Model Pengajaran dan Pembelajaran. Yogyakarta: Pustaka Pelajar Celeban Timur.

Molle dan La Moma. (2008). Pembelajaran Kooperatif Di SMP Dan SMU Pada Materi Pelajaran Matematika Di Provinsi Maluku. Buletin Pendidikan Matematika 10 (1): Program Studi Pendidikan Matematika FKIP Universitas Pattimura: Ambon.

Pattimukay, (2008). Model Pembelajaran Kuantum Untuk Sub Materi Segitiga di Kelas VII SMP Kristen Petra 2 Surabaya. Buletin Pendidikan Matematika 10 (1). Program Studi Pendidikan Matematika FKIP Universitas Pattimura. Ambon.

Purwanto. (2009). Evaluasi Hasil Belajar. Yogyakarta: Pustaka Pelajar

Ratumanan, T. G. (2002). Strategi Belajar dan Pembelajaran. Surabaya: Universitas Negeri Surabaya Press.

Ratumanan, T. G. (2006). Belajar dan Pembelajaran. Surabaya: Universitas Negeri Surabaya Press.

Sanjaya, W. (2011). Kurikulum dan Pembelajaran: Teori dan Praktik Pengembangan Kurikulum Tingkat Satuan Pendidikan (KTSP). Jakarta: Kencana.

Setyosari, P. (2012). Metode Penelitian Pendidikan dan Pengembangan. Jakarta: Prenada Media Group.

Slameto. (2003). Belajar dan Faktor-faktor yang Mempengaruhinya. Jakarta: Rineka Cipta.

Sugiyono. (2014). Statistika Untuk Penelitian. Bandung: Alfabeta.

Sugiyono. (2015). Statistika Untuk Penelitian. Bandung: Alfabeta.

Tanujaya, B. (2013). Penelitian Percobaan. Bandung: Remaja Rosdakarya. 
Tanujaya, B., Prahmana, R.C.I., \& Mumu, J. 2017. Mathematics instruction, problems, challenges and opportunities: a case study in Manokwari Regency, Indonesia. World Transactions on Engineering and Technology Education, 15(3), 287-291.

Trianto. 2009. Mendesain Model Pembelajaran Inovatif Progresif. Jakarta: Kencana. 
Niak, Mataheru \&Ngilawayan: Perbedaan Hasil Belajar Model Pembelajaran Kooperatif Tipe CIRC dan Model Pembelajaran Konvensional. 